\title{
TERTUllianus ON THE PERICOPE ADULTERAE (JOHN 7,53-8,11)
}

\author{
Abstract \\ Although Terullianus is deeply engaged in discussions on Christian marriage, adultery, and on \\ the remission of (grave) sins, he never addressed the story of the woman caught in adultery known \\ today from the Gospel of John. This essay argues that his silence cannot be explained by \\ suppression because of the explosive nature of the story in relation to penitential discipline and to \\ his own views and arguments. Rather, it proposes that the pericope adulterae was unknown in \\ Carthage at his time.
}

\section{Introduction}

The story of the woman caught in adultery in the Gospel of John $(7,53-8,11)$ represents one of the most mysterious New Testament passages. Omitted in early manuscripts, the circulation and dissemination of the pericope adulterae (henceforth the PA) is controversially discussed. Already C. R. Gregory (1846-1917) claimed that the PA had been "very often read, and especially at a very early time."1 H. Riesenfeld (1913-2008) assessed that the Latin translation of the passage "appears sporadically before the Vulgate and then in the entire Vulgate tradition."2 This judgement has been criticised by T. O'Loughlin. Based on the number of extant Vetus Latina fragments, he came to the conclusion that the PA "was more likely [included] than not to have been present [in the Vetus Latina] prior to the dominance of the Vulgate." 3 According to J. W. Knust, "the pericope was present only in a few copies of John in the early second century-which seems to be a likely conclusion given the patristic and manuscript evidence." ${ }^{\prime 4}$ In a statement—often considered as the actual communis opinio-, B. Metzger (1914-2007) summarises the following: "It [i.e., PA] is obviously a piece of oral tradition which circulated in certain parts of the Western church and which

1 Caspar René Gregory, Canon and Text of the New Testament, (International theological library), Edinburgh, Clark, 1907, p. 514.

2 Harald RIESENFELD, The Pericope de adultera in the Early Christian Tradition, in E. Margaret RowLEY (ed.), The Gospel Tradition: Essays, Philadelphia, Fortress Pr., 1970, p. 97. The original essay was published in Harald RIESENFELD, Perikopen de adultera i den fornkyrkliga traditionen, in Svensk exegetisk årsbok, (1952).

3 Thomas O'Loughlin, A Woman's Plight and the Western Fathers, in L. Joseph KreITZER (ed.), Ciphers in the Sand: Interpretations of the Woman Taken in Adultery (John 7.53 - 8.11), (The Biblical seminar, 74), Sheffield, Sheffield Academic Press, 2000, p. 86. Based on a preview of the compilation of Bonifatius FISCHER, Die lateinischen Evangelien bis zum 10. Jahrhundert Bd. 4: Varianten zu Johannes, (Vetus Latina / Aus der Geschichte der lateinischen Bibel, 18), Freiburg, Herder, 1991, p. 242-278, he counts just three Vetus Latina manuscripts that omitted the story while seven of them included it. With an annotation to the possible fallacy of the small numbers he concludes that "it was twice as likely for a codex to contain it, than to omit it".

4 Jennifer Wright KNUST, Jesus, an Adulteress, and the Development of Christian Scripture, in Jean-Jacques AUBERT (ed.), A Tall Order. Writing the Social History of the Ancient World. FS William V. Harris, (Beiträge zur Altertumskunde, 216), München, Saur, 2005, p. 74. 
was subsequently incorporated into various manuscripts at various places."5 The open phrasing of this verdict represents not only an appropriate circumspection but also shows the numerous uncertainties that the famous passage still maintains. This analysis intends to scratch deeper than the surface in order to re-examine-at least in part—the claimed "wide" dissemination of the PA. More precisely, it aims to determine, whether Carthage (and North Africa?) belonged to the "certain parts of the Western church", where the story was read or told in "very early" times. The legacy of Tertullianus ( $\dagger$ after 220 ), the discourse of pardoning at the beginning of the $3^{\text {rd }}$ century, and the manuscript tradition shall shed some light on this rather obscure matter.

\section{Preliminary remarks}

More than four decades ago, H. von Campenhausen (1903-1989) made a remarkable observation concerning the dissemination of PA: "[D]ie Perikope [spielt] in den großen

Bußauseinandersetzungen um 200 noch nirgends eine Rolle." ${ }^{\prime 6}$ Scholars thought for many years that they were in possession of the answer to this question before it had even been raised. The origins of the "suppression theory", which is still popular, ${ }^{7}$ lead us back as far as to the end of the $19^{\text {th }}$ century, but has its roots in Late Antiquity. The hypothesis is based on the presumption that the PA was omitted from the canonical Gospels because of its alleged explosive content ${ }^{8}$ in contrast to primitive

5 Bruce Manning Metzger, A Textual Commentary on the Greek New Testament: A Companion Volume to the United Bible Societies' Greek New Testament, Stuttgart, Deutsche Bibelgesellschaft, ${ }^{4} 2006$, p. $187 \mathrm{ff}$.

6 Hans CAMPENHAUSEN, Zur Perikope von der Ehebrecherin (Joh $753-8$ 11), in Zeitschrift für die Neutestamentliche Wissenschaft, 68 (1977), p. 164f.

7 See for example Henry J. CADBURY, A Possible Case of Lukan Authorship (John 7 53-8 11), in The Harvard Theological Review, 10 (1917), p. 243 n. 14; Eric F. BISHOP, The Pericope Adulterae: A Suggestion, in Journal of Theological Studies, 35 (1934), p. 40.42; Walter GRUndMANn, Das Evangelium nach Markus, (Theologischer Handkommentar zum Neuen Testament, 2), Berlin, Evang. Verl.-Anst., ${ }^{5} 1971$, p. 224; Allison A TRITES, The Woman Taken in Adultery, in Bibliotheca sacra, 131 (1974), p. 145; Zane C. HoDGES, The Woman Taken in Adultery (John 7:53-8:11): Text, in Bibliotheca sacra, 136 (1979), p. 331; Gary M. BuRGE, A Specific Problem in the New Testament Text and Canon: The Woman Caught in Adultery (John 7:53-8:11), in Journal of the Evangelical Theological Society, 27 (1984); Gail R. O'DAY, John 7:53-8:11: A Study in Misreading, in Journal of Biblical Literature, 111 (1992), p. 639f; Josep RIUS-CAMPS, Origen Lucano de la Pericopa de la Mujer Adultera (Juan 7:53-8:11), in Filología Neotestamentaria, 6 (1993), p. 173f; Martin SCOTT, On the Trail of a Good Story: John 7.53-8.11 in the Gospel Tradition, in L. Joseph KREITZER, Deborah W. ROOKE (ed.), Ciphers in the Sand: Interpretations of the Woman Taken in Adultery (John 7.53 - 8.11), (The Biblical seminar, 74), Sheffield, Sheffield Academic Press, 2000, p. 72-77; O'Loughlin, Plight [see n. 3], p. 101; Josep RIUS-CAMPS, The Pericope of the Adulteress Reconsidered: The Nomadic Misfortunes of a Bold Pericope, in New Testament Studies, 53 (2007), p. 383; John David Punch, The Pericope Adulterae: Theories of Insertion \& Omission, Nijmegen, Radboud Universiteit, 2010, p. esp. 356-360; John David Punch, The Piously Offensive Pericope Adulterae, in David Alan BlACK, Jacob N. CERONE (ed.), The Pericope of the Adulteress in Contemporary Research, (The Library of New Testament Studies, 551), New York, Bloomsbury T\&T Clark, 2016.

8 The assumed "dangerous nature" of being indulgent towards adulteresses can be easily verified by sources from beginning of the $3^{\text {rd }}$ century. E.g. Tertullianus, De pudicitia 21,7 (CC.SL 2, 1326,27-31). In vivid examples, the anonymous Author of the Refutatio omnium haraesium - traditionally attributed to Hippolytus (Romanus)-demonstrates the "hazardous" nature of leniency maintained by his episcopal enemy, Calixtus I. (217?-222?) of Rome on three levels. First, it had led to digamy and trigamy among the clergy. Second, bishops might have remained in office although they committed deadly sins. Third, young Christian clarissima feminae have lived together with male (sexual) partners of lower social status without a legal marriage. Refutatio omnium haeresium 9, 12, 21-25 (GCS 26,3, 249,18-251,1). 
Christian discipline. A passage found in Augustinus (354-430), confirmed such considerations. ${ }^{9}$ Recently, J. Knust and T. Wasserman presented convincing arguments against an omission ${ }^{10}$ which I will complement with an additional aspect. The "suppression theory" implies some fundamental paradigms of the study of the history of the dogma, the predominant approach of ecclesiastical historiography in the last two centuries. For instance, it is based on the assumption that a linear and universal development of dogma and discipline had taken place across place and time. ${ }^{11}$ Recent scholarship, however, describes the development from the beginning as a heterogeneous phenomenon. The New Testament testifies to highly diversified views on hamartiology, on the possibility of remission or on the practice of penance. ${ }^{12}$ Rigorous positions coexisted-even in a relatively geographically closed environment like Rome, Antioch, or Alexandria-with "lenient" or moderate views, depending on the unique traditions of each group or community. This versatility is still present at the beginning of the $3^{\text {rd }}$ century. ${ }^{13}$ Therefore, disciplinary concerns originating in the local theological tradition of a particular community cannot explain the widespread omission of the PA. Moreover, it remains entirely unanswered what kind of ecclesiastical authority could have possessed sufficient and obviously supra-regional control over the Scriptures in order to force, perform, or maintain such a "censorship" during the first three centuries. Consequently, the "suppression theory" can neither provide a persuasive solution for an omission, nor can it deliver a

9 Augustinus, De adulterinis coniugiis 2, 6, 7 (CSEL 41, 387,25-388,6).

10 Jennifer Wright KnUst, 'Taking Away From:' Patristic Evidence and the Omission of the Pericope Adulterae from John's Gospel, in David Alan BLACK, Jacob N. CERONE (ed.), The Pericope of the Adulteress in Contemporary Research, (The Library of New Testament Studies, 551), New York, Bloomsbury T\&T Clark, 2016; Tommy Wasserman, The Strange Case of the Missing Adulteress, in David Alan BlaCK, Jacob N. CERONE (ed.), The Pericope of the Adulteress in Contemporary Research, (The Library of New Testament Studies, 551), New York, Bloomsbury T\&T Clark, 2016.

11 Two of the most-and still-influential titles are: Bernhard Poschmann, Paenitentia secunda: Die kirchliche Buße im ältesten Christentum bis Cyprian und Origenes. Eine dogmengeschichtliche Untersuchung, (Theophaneia, 1), Bonn, Hanstein, 1940; Hans CAMPENHAUSEN, Kirchliches Amt und geistliche Vollmacht in den ersten drei Jahrhunderten, (Beiträge zur historischen Theologie, 14), Tübingen, Mohr, ${ }^{2} 1963$.

12 Cf. Ingrid GoldhaHN-Müller, Die Grenze der Gemeinde: Studien zum Problem der Zweiten Busse in Neuen Testament unter Berücksichtigung der Entwicklung im 2. Jh. bis Tertullian, (Göttinger theologische Arbeiten, 39), Göttingen, Vandenhoeck \& Ruprecht, 1989; Helmut UMBACH, In Christus getauft - von der Sünde befreit: die Gemeinde als sündenfreier Raum bei Paulus, (Forschungen zur Religion und Literatur des Alten und Neuen Testaments, 181), Göttingen, Vandenhoeck \& Ruprecht, 1999; Stephan HAGENOW, Heilige Gemeinde - Sündige Christen: Zum Umgang mit postkonversionaler Sünde bei Paulus und in weiteren Texten des Urchristentums, (Texte und Arbeiten zum neutestamentlichen Zeitalter, 54), Tübingen, Francke, 2011.

13 In the Shepherd of Hermas (Rome, ca. 150), one can acknowledge at least three different positions. First, he propagates a single possibility of penance for grave sins after baptism. See, e.g., Hermas, Mandata, 4, 1,8 (GCS Hermas, 26,16-20). Second, he mentions other "teachers" who deny the general possibility of a paenitentia secunda. Mandata, 4, 3,1f (GCS Hermas, 27,21-28,3). Finally, when he discusses his own sins, he seems to know and practice some kind of (public?) exomologesis. Visiones 1, 1, 3; 1, 1, 9 and 1, 3, 2 (GCS Hermas, 1,7-14; 2,1417; 3,16-4,2). Some 70 years later, the Author of the Refutatio omnium haeresium mentions the followers of Marcos the Magician, who are "indifferent to sin". Refutatio omnium haeresium 6, 41, 1, (GCS 26,3, 172,19f): “...

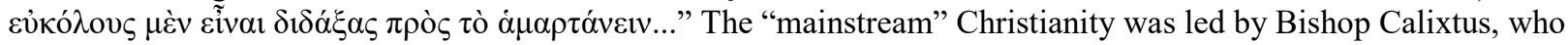
proclaimed the pardoning of adultery. Refutatio omnium haeresium 9, 12,20 (GCS 26,3, 249,13-18). See also n. . Furthermore, it is likely that the Roman section of the New Prophets-similar to their North African branch-propagated rather strict discipline. Refutatio omnium haeresium 8, 19 (GCS 26,3, 238,4-25). See also William TABBERnEE, Fake Prophecy and Polluted Sacraments: Ecclesiastical and Imperial Reactions to Montanism, (Vigiliae Christianae / Supplements, 84), Leiden/Boston, Brill, 2007, p. 68ff. 
substantial clarification of the observation of Campenhausen.

It must be also noted, that the narrative now referred to as the PA, shows a rather heterogeneous appearance in the ancient sources. ${ }^{14}$ It has, however, only rudimentary impact, if any, on this examination due to the general attitude of Tertullianus to female sinners. He identifies, e.g., the unspecified sin of the weeping woman according to Lk. 7,36f in De pudicitia as adultery. ${ }^{15}$

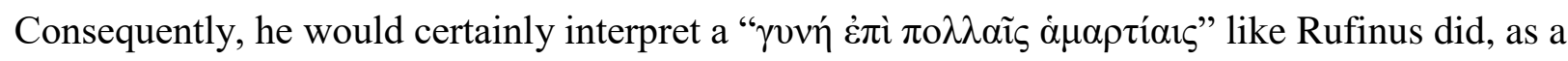
"muliere adultera". 16

\section{The assumed initial locations of the PA within the oeuvre of Tertullianus}

It is commonly recognised that the comprehensive work of Tertullianus does not refer-neither explicitly nor implicitly- to the story of the adulteress. ${ }^{17}$ This is remarkable, since the problems that the PA is dealing with represent a fundamental concern for the Carthaginian. Independently from the increasing influence of the New Prophecy ${ }^{18}$ on his theological thinking, ${ }^{19}$ these issues employed him during the entire period of his literary production. Works like Ad uxorem libri duo, De culto feminarium, De exhortatione castitatis, De monogamia, De pudicitia and parts of De paetiantia and De virginibus velandis tackle such matters extensively. He had indeed ample opportunities to comment on or condemn it as evidence. But this never happened in his extant writings.

In order to get closer to a more precise understanding of Tertullianus' silence, it is essential to determine whether he has all the necessary sources available to learn about the story of the adulteress. Since the transmission history of the passage is still a matter of discussion, ${ }^{20}$ scholars regard it either as part of the free-floating oral and written (agraphon) tradition, or that of the already fixed written tradition. In the second case, whether one accepts the "suppression theory" or

14 Cf., for example, Ulrich BECKER, Jesus und die Ehebrecherin: Untersuchungen zur Text- und Überlieferungsgeschichte von Joh. 7,53 - 8,11, (Zeitschrift für die neutestamentliche Wissenschaft / Beihefte, 28), Berlin, Toepelmann, 1963, p. 37-43; Bart D. EHRMAn, Jesus and the Adulteress, in New Testament Studies, 34 (1988); Dieter LÜHRMANN, Die Geschichte von einer Sünderin und andere apokryphe Jesusüberlieferungen bei Didymos von Alexandrien, in Novum Testamentum, 32 (1990); Jennifer Wright KNUST, Early Christian Re-Writing and the History of the Pericope Adulterae, in Journal of Early Christian Studies, 14 (2006).

15 De pudicitia 11, 1f (CC.SL 2, 1301,1-1302,10) and see p. 11f.

16 Eusebius, Historia Ecclesiastica 3, 39, 17 (GCS Eusebius 2/1, 293,7ff).

17 Already noted by Granville PENN, Johann Leonhard HUG, Annotations to the Book of the New Covenant, with an expository preface, London : J. Duncan, 1837, p. 267-268.

18 The New Prophecy refers to the self-designation of Montanism, an early Christian ecstatic movement of the late $2^{\text {nd }}$ century originated in Phrygia. See hereto Christoph MARKSCHIES, Montanismus, in Reallexikon für Antike und Christentum, 24 (2012).

19 To the development of his theological thinking concerning penance see Mark DEVINE, Two Treatises on Penance: An Inquiry into Tertullian's Exegesis and Montanism, in Churchman, 109 (1995); Laurence MELLERIN, La contribution de Tertullien à la réflexion théologique sur l'irrémissible: du De paenitentia au De pudicitia, in Revue des Études Augustiniennes et Patristiques, 58 (2012).

20 For a summary of the previous research and a discussion of the question see Chris KEITH, Recent and Previous Research on the Pericope Adulterae (John 7.53-8.11), in Currents in Biblical Research, 6 (2008), p. 379-384. For the state-of-the-art see Jacob N. CERONE, David Alan BLACK (ed.), The Pericope of the Adulteress in Contemporary Research, (The Library of New Testament Studies, 551), New York, Bloomsbury T\&T Clark, 2016. 
not, some scholars determine the assumed initial location within the canonical Gospels, while others ascribe it to non-canonical texts.

Facing the enormous amount of biblical references in the writings of Tertullianus, ${ }^{21}$ it is obvious that he frequently used the Scriptures. He seems to know almost all canonical and deuterocanonical books. ${ }^{22}$ Within the fourfold Gospels-with some simplification- there are seven positions that scholars or survived manuscripts ${ }^{23}$ suggest for the allocation of the PA: in the Gospel of Mark after

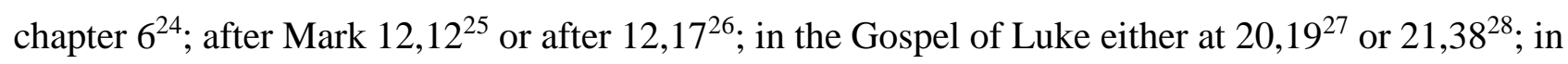
the Gospel of John after 7,36 ${ }^{29}$, after the actual position at 7,53 (which is considered also as the earliest demonstrable position), or as an "appendix" after 21,25 $5^{30}$. A cross-checking of the references (see Table 1.) reveals that he refers without exception to passages in proximity to those assumed locations. Consequently, had his version of the Scriptures included the story, he should have come across it.

\begin{tabular}{|c|c|c|c|c|c|}
\hline \multicolumn{2}{|l|}{ Mark } & \multicolumn{2}{|l|}{ Luke } & \multicolumn{2}{|l|}{ |John } \\
\hline 5,48 & Bapt. 9,4 & 20,6 & AdvMarc. 4, 38,1 & 7,33 & AdvPrax. 22,2 \\
\hline 6,53 & Bapt. 9,4 & 20,8 & AdvMarc. 4, 38,2 & $7,38 \mathrm{f}$ & Resurr. 26,10 \\
\hline 6,57 & PA & 20,19 & PA & $7,53-8,11$ & $\mathbf{P A}$ \\
\hline 7,6 & AdvMarc. 4, 17,13 & $20,20-26$ & AdvMarc. 4, 38,3 & 8,12 & AdvPrax. 13,8 \\
\hline 11,30 & Bapt. 10,1 & 20,25 & Coron. 12,4 & 8,16 & AdvPrax. 22,2 \\
\hline 12,16 & Coron. 12,4 & 21,36 & Resurr. 22,8 & 8,17 & Praescr. 22,6 \\
\hline $12,12 / 12,17$ & PA & $21,37 f$ & AdvMarc. 4, 39,9 & 21,28 & Scorp. 15,3 \\
\hline
\end{tabular}

21 According to the Biblindex (http://www.biblindex.mom.fr), the oeuvre of Tertullianus contains more than 2,400 scriptural references and allusions.

22 These are Ruth, Obadiah, 1 Chronicles, Esther, 2 Maccabees, 2 John, and 3 John.

23 For a comprehensive review of the previous research see KeITH, Recent and Previous Research on the Pericope Adulterae (John 7.53-8.11) [see n. 19], p. 384ff; Chris KeITH, The Initial Location of the 'Pericope Adulterae' in Fourfold Tradition, in Novum Testamentum, 51 (2009); The Pericope Adulterae, the Gospel of John, and the literacy of Jesus, (New testament tools, studies and documents, 38), Leiden/Boston, Brill, 2009, p. 119-140.

24 Cf. Hermann Von SOdEn, Die Schriften des Neuen Testaments in ihrer ältesten erreichbaren Textgestalt, hergestellt auf Grund ihrer Textgeschichte. Teil I: Untersuchungen. Abteilung III: Die Textformen: B. Der Apostolos mit der Apokalypse, Berlin, Duncker, 1910, p. 2150. For the discussion around the judgement of von Soden see KeITH, Initial Location [see n. 22], p. 212, n. 13.

25 Cf. RIUS-CAMPS, Pericope [see n. 7], p. 383.

26 Cf. GRUNDMANN, Theologischer Handkommentar zum Neuen Testament; Bd. 2 [see n. 7], p. 245-247; Herman C. WAETJEN, The Gospel of the Beloved Disciple: A Work in Two Editions, New York, NY, T \& T Clark, 2005, p. 233 , n. 36.

27 Cf. Rius-CAMPS, Lucano [see n. 7].

28 Most manuscripts that insert the PA here belong to the "Family 13". See further Friedrich BLASS, Philology of the gospels, London/New York, Macmillan, 1898, p. 158; BISHOP, Pericope [see n. 7]; RIESENFELD, The Pericope de adultera [see n. 2], p. 95; KNUST, Development [see n. 4], p. 61.

29 Minuscle 225. Further suggestions for the Gospel of John: Maurice A. RoBINSON, Preliminary Observations Regarding the Pericope Adulterae based upon Fresh Collations of nearly all Continuous-Text Manuscripts and all Lectionary Manuscripts containing the Passage, in Filologia neotestamentaria, 13 (2000).

30 Family 1, minuscules 20,37, 135, 207, 301, 347 as well as most Armenian translations integrate the PA at this position. 


\begin{tabular}{|ll||ll||ll}
$12,18-23$ & Res. 36,1 & $\mathbf{2 1 , 3 8}$ & PA & 21,23 & Anim. 50,5 \\
12,25 & Uxor. I. 1,5 & 22,1 & AdvMarc. 4, 40,1 \\
12,30 & AdvMarc. 2, 13,5 & $22 ; 3$ & AdvMarc. 5, 6,7
\end{tabular}

Table 1. Biblical references or allusions of Tertullianus in the context of the assumed initial positions of the PA.

For the circulation of the story, scholars and ancient sources suggest two other possibilities within the written tradition. Though it is a rather lonely opinion, the PA is considered by some to be a part of the "Q". ${ }^{31}$ A reference of Papias, the bishop of Hierapolis in Asia Minor, bequeathed by Eusebios of Caesarea, mentions a not further specified "Gospel according to the Hebrews" as the initial source. ${ }^{32}$ The suggestion that the story is part of the $\mathrm{Q}$ would raise more questions than it would solve problems. ${ }^{33}$ The "Gospel according to the Hebrew" is hardly conclusive on the matter: since an overwhelming part of it is lost, it is the reception history that offers the most information on the text. Remarkably there is a strong geographical focus on Egypt: One can find references and allusions to this Gospel only by authors who had either an Egyptian background or were (temporarily) residents. ${ }^{34}$ Both this restriction and the fact that the no works of Tertullianus quote or allude to anything identifiable as this Gospel point in the same direction: it is not unlikely that it was known in Carthage. But even if it was known, the apparent ignorance points to a possible alternative: the suppression of the text as a legitimate source of authoritative tradition. ${ }^{35}$

In recent times, the opinion that the PA is "homeless", i.e., that it is part of the oral tradition prior to its integration into the Gospel of John, has gained more and more popularity. ${ }^{36}$ Fortunately, the writings of Tertullianus provide some information on his attitude and that of his adversaries towards the authority of the oral tradition. Moreover, they also present a few examples of its useage. To Tertullianus, like to many others in his age,${ }^{37}$ the oral tradition was an integral part of the tradition

31 Cf. Beverley Warren Coleman, Woman Taken in Adultery, in Theology, 73 (1970).

32 Historia Ecclesiastica 3, 39, 17 (GCS Eusebius 2/1, 292,8-10).

33 If the PA is, as suggested, indeed part of the Q, it has to be plausibly explained inter alia, why John-and especially why only John-incorporates it while the Gospels according to Matthew and Luke ignore it.

34 Cf. Jörg FREY, Die Fragmente judenchristlicher Evangelien, in Christoph MARKSCHIES et al. (ed.), Antike Christliche Apokryphen in Deutscher Übersetzung. Bd. I: Evangelien Und Verwandtes. Teilbd. 1, Tübingen, Mohr Siebeck, ${ }^{7} 2012$, p. 597f; 602.

35 Origenes, Commentarii in Ioannem 2, 12 (GCS Origenes 4, 67,19ff); Homiliae in Ieremiam, 15, 4 (GCS Origenes 3, 128,26ff); Hieronymus, in Michaeam 2 (= CC.SL 76, 513,306-309); Hieronymus, De viris illustribus 2, $12 \mathrm{f}$ (BPat 12,78); Didymus, Expositio in Psalmos Ps 33, 1 (PTA 8, 184,9ff) and see further EHRMAN, Adulteress [see n. 14], p. 25-38.

36 Cf. Patricia Klindienst JOPLIN, Intolerable Language: Jesus and the Woman Taken in Adultery, in Philippa BERRY (ed.), Shadow of Spirit: Postmodernism and Religion, London/New York, Routledge, 1992, p. 227; Hans-Josef KLAUCK, Apocryphal Gospels: An Introduction, London, Clark, 2003, p. 19; Frances Taylor GENCH, Back to the Well: Women's Encounters with Jesus in the Gospels, Louisville, Ky., Westminster John Knox Press, 2004, p. 156; KnUSt, Development [see n. 4], p. 73f; Chris KEITH, A Theory of Attentive Insertion, in David Alan BLACK, Jacob N. CERONE (ed.), The Pericope of the Adulteress in Contemporary Research, (The Library of New Testament Studies, 551), New York, Bloomsbury T\&T Clark, 2016.

37 Of mention is inter alia Papias, Ireneus, Clement of Alexandria, Origenes, and "Hippolytus". Cf. Richard P. C HANSON, Tradition in the Early Church, (The library of history and doctrine), London, SCM Press, 1962, p. 35-51. He notes at p. 50, however, "that by the middle of the second century this [i.e., oral] tradition was subject to a 
(traditio) of the (true) church and as such indeed an authoritative entity. ${ }^{38}$ The main characteristics of the true church (due to its direct deliverance from the apostles, the apostles from Christ, and Christ from $\mathrm{God}^{39}$ ) in contrast to the heretics are that it maintains "the true Christian discipline and faith, the true Scriptures and expositions of them, and all the Christian traditions" ${ }^{\text {"40 }}$. Although Tertullianus distinguishes clearly between written (the Scriptures) and non-written (disciplina ${ }^{41}$ and "Christian traditions") traditions, the terms appear here as equivalent. They are not identical with, but subordinated to the rule of faith (regula fidei). ${ }^{42}$ The Scripture is a written record of the revelation as a Word of God, who becomes flesh in Christ. ${ }^{43}$ The apostles, who received the revelation of Christ in person, proclaimed the message in the churches and kept it there for generations. ${ }^{44}$ The apostolic tradition, which is nothing less than the teachings of the apostles, together with the regula fidei, form the oral tradition. In his later days, Tertullianus also considered the oracles of the Paraclete as a fundamental part of the tradition, because it "dispels all former ambiguities" $" 45$. Therefore, it is hardly surprising that he uses them in no less than 34 cases as a source of (from his perspective) authentic legitimation. ${ }^{46}$ This approach is essential, because the

growing uncertainty and by the middle of the third century it was so faint as to be almost non-existent".

38 De praescriptione haereticorum 21, 3 (CC.SL 1, 202,6-10): “Quid autem praedicauerint, id est quid illis christus reuelauerit et hic praescribam non aliter probari debere nisi per easdem ecclesias quas ipsi apostoli condiderunt, ipsi eis praedicando tam uiua, quod aiunt, uoce quam per epistulas postea." Tertullianus maintains two different concepts of traditio. First, he describes with traditio what the apostles taught in contrast to the written word. Second, tradition is basis of the Christian ethics, customs, and practice. In this perspective, there are flourishing various traditions. Cf. Ellen FLESSEMAN-VAN LEER, Tradition and Scripture in the Early Church, (Van Gorcum's theologische bibliotheek, 26), Assen, Van Gorcum, 1954, p. 145-150.

39 De praescriptione haereticorum 21, 4 (CC.SL 1, 202,10-203,14).

40 De praescriptione haereticorum 19, 3 (CC.SL 1, 201,8-11): "Vbi enim apparuerit esse ueritatem disciplinae et fidei christianae, illic erit ueritas scripturarum et expositionum et omnium traditionum christianarum."

41 It is important to note that disciplina is one of the synonyms (among veritas, fides, and regula fidei), Tertullianus is uses to describe the revelation that the apostles received from Christ and transmitted in the church. Georg Günter BLuM, Tradition und Sukzession: Studien zum Normbegriff des Apostolischen von Paulus bis Irenäus, (Arbeiten zur Geschichte und Theologie des Luthertums, 9), Berlin, Lutherisches Verlagshaus, 1963, p. 103; 112; Thomas Gerhard RING, Auctoritas bei Tertullian, Cyprian und Ambrosius, (Cassiciacum, 29), Würzburg, Augustinus-Verl., 1975, p. 66-72; Heinz OHME, Kanon ekklesiastikos: die Bedeutung des altkirchlichen Kanonbegriffs, (Arbeiten zur Kirchengeschichte, 67), Berlin/New York, de Gruyter, 1998, p. 99-116. He distinguishes in De pudicitia between disciplina and potestas of the apostles, but only attributes the former to the church of the "sensualists". Consequently, he recognises their traditions as true and apostolic and being in accordance with the regula fidei.

42 See hereto Frans de PAUw, La justification des traditions non écrites chez Tertullien, (Sylloge excerptorum e dissertationibus ad gradum doctoris in sacra theologia vel in iure canonico consequendum conscriptis, 19,1), 1942, p. 44; FLESSEMAN-VAN LEER, Tradition [see n. 37], p. 161-170; Louis W. COUNTRYMAN, Tertullian and the regula fidei, in The Second Century, 2 (1982), p. 214-218; Everett FERGuson, Paradosis and Traditio: A Word Study, in Ronnie J. Rombs (ed.), Tradition and the Rule of Faith in the Early Church: Essays in Honor of Joseph T. Lienhard, Washington, D.C., Catholic Univ. of America Press, 2010, p. 18-21; OHME, Kanon [see n. 40], p. 78121.

43 De resurrectione mortuorum 63, 6 (CC.SL 2, 1012,23-28).

44 De praescriptione haereticorum 20 4-8 (CC.SL 1, 201,12-202,28).

45 De resurrectione mortuorum 63, 9 (CC.SL 2, 1012,42-46): “... idcirco iam omnes retro ambiguitates et quantas uolunt parabolas aperta atque perspicua totius sacramenti praedicatione discussit per nouam prophetiam de paraclito inundantem."

46 See Ronald E. HeINE (ed.), The Montanist Oracles and Testimonia, (Patristic monograph series, 14), Macon, Ga, Mercer Univ. Pr., 1989, p. 62-93. 
revelations ${ }^{47}$ often go beyond the Scriptures. His adversaries are obviously aware of the weak point of such an argumentation: once they accuse him with "novelty in opposition to the catholic tradition" 48 . Probably in order to avoid easy objections, Tertullianus predominantly prefers to support his views by those authorities that are commonly accepted, also by his opponents. When they, however, exceptionally leave the field of the Scriptures, he also utters an obliterative critique. ${ }^{49}$ It seems that both parties are aware of the weaknesses of using non-written or extracanonical traditions. Nonetheless, especially in acute shortage of authoritative arguments, both sides hesitate little to legitimate their own views therewith. A further characteristic of the non-written tradition-when it is stated as the rule of the faith-is its general limitation to disciplinary matters. ${ }^{50}$ For instance, Tertullianus justifies some particular practices for baptism with the oral tradition. ${ }^{51}$ Since the discourse of pardoning is such a matter, one can observe this phenomenon particularly well in De pudicitia. Both sides call for external, i.e., non-written, non-canonical support: while Tertullianus declares his view on modesty and the purity of the church to the universal and apostolic rule of faith, ${ }^{52}$ his opponents use the authority of the Shepherd of Hermas. ${ }^{53}$ In another case, the "Catholics" 54 do not only seize on the oral tradition, but—similar to Tertullianus-they recognise its authority as being equivalent to the Scriptures. ${ }^{55}$

To sum up, it seems that there is very little difference between the written and the non-written tradition concerning its authority. Both Tertullianus and the "Catholics" accept it and use it as an

47 The revelations of the Paraclete do not need any kind of further scriptural authority because they do not contradict but rather imply the scriptures, as Tertullianus tries to demonstrate. De idolatria 4, 5 (CC.SL 2, 1104,8-12) and cf. FLESSEMAN-VAN LEER, Tradition [see n. 37], p. 156f.

48 De monogamia 2,1 (CC.SL 2, 1230,5ff): “....an capiat paracletum aliquid tale docuisse quod aut nouum deputari possit aduersus catholicam traditionem aut onerosum aduersus leuem sarcinam Domini."

49 See hereto his attitude towards the Pastor Hermae in n. .

50 The phenomenon can be observed in De pudicitia 1 (CC.SL 2, 1281,1-1283,94); in De corona militis 1-2 (CC.SL 2, 1039,1-1042,35) and in De ieiunio adversus psychicos 1-2 (CC.SL 2, 1257,1-1259,29). Cf. PAUW, Justification [see n. 41], p. 26; FLESSEMAN-VAN LEER, Tradition [see n. 37], p. 158f; and especially OHME, Kanon [see n. 40], p. 8892-121.

51 De corona militis 3-4 (CC.SL 2, 1042,35-1045,47).

52 De pudicitia 1 (CC.SL 2, 1281,1-1283,94).

53 De pudicitia 10, 12 (CC.SL 2, 1301,45-54).

54 One can observe in the writings of Tertullianus the presence of a quite heterogeneous Christianity in Carthage. Cf. Victor SAXER, Das christliche Afrika (180-260), in Jean-Marie MAYEUR, Luce PIETRI, Norbert BROX (ed.), Die Geschichte Des Christentums, Bd. I: Die Zeit Des Anfangs (Bis 250), Freiburg im Breisgau, Herder, 2003, p. 626641; Éric REBILLARD, Christians and Their Many Identities in Late Antiquity, North Africa, 200-450 CE, Ithaca/London, Cornell University Press, 2012, p. 9-33; François DECRET, Early Christianity in North Africa, Cambridge, James Clarke \& Co, 2014, p. 9-32. Its implications to the organisation of the church remains, however, largely obscure. It seems Tertullianus knows only one bishop in Carthage, but he does not reveal his name. See infra, n. . It is also unclear whether this bishop was the only bishop of Carthage and whether he represented the Mehrheitskirche, as it is commonly assumed, or only one larger group of Christians among many others. The relationship between the Carthaginian branch of the New Prophets and that of the "Catholics" on the level of church organisation is even less clear. Consequently, it is not self-evident to declare the Christianity represented by the anonymous bishop as "Catholic" or as the "majority church" or to call it simply "orthodoxy". Due to a lack of adequate terminology, I prefer using the expression "Catholic" in quotation marks for the church of the anonymous bishop.

55 De ieiunio adversus psychicos 13, 1 (CC.SL 2, 1271,13ff): "Praescribitis constituta esse sollemnia huic fidei scripturis uel traditione maiorum nihilque obseruationis amplius adiciendum ob illicitum innouationis." 
authentic foundation. Simultaneously, the rhetorical vulnerability of such an argument is acknowledged. Since written and non-written traditions are considered and used in Carthage as sources of equal authority, the form of the transmission of the PA does not play a particular role when it comes to claims of legitimacy.

\section{Tertullianus and the North African discourse on the pardoning of adultery}

Around 200, the possibilities and limits of divine grace towards baptised Christians that have fallen into sin were fervently discussed. This process interfered persistently with the progress of the hierarchisation and the professionalisation of the clergy and led to a massive expansion of episcopal competence. The reconsideration of the strict non-repeatability of paenitentia secunda, its integration into an institutionalised exomologesis administrated mainly by the bishop, and the question of which sins can be forgiven and which are not to be pardoned in a process of public penance, mark the major issues. In these debates, Tertullianus lifted his "moral index finger" at least twice.

De paenitentia, written presumably around $200,{ }^{56}$ has little relevance. The aim of the booklet-to instruct catechumens on the virtue of penitence and to demonstrate the practice of the church-is limiting in its scope ${ }^{57}$ Biblical explanations remain brief, pointed and uncompleted. Therefore, it is sufficient to observe that De paenitentia does not refer to the narrative.

The second work, De pudicitia, most likely represents his last extant writing. The treatise is characterised as a (highly) "polemic pamphlet", which maintains "a passionate, bigoted and yet utterly sincere attack on the doctrine and discipline of the orthodox Church", and reveals its author as a "true fanatic". ${ }^{58}$ Such an assessment is, however, as popular as it is short-sighted. ${ }^{59}$ The work attacks two adversaries: ${ }^{60}$ the "sensualists" (psychici) in general, i.e., the non-followers of the New Prophecy and an anonymous personal opponent in particular. His identity remains in the dark, but it is highly likely that he is the bishop of the "Catholics". A precise identification with Bishop

56 The traditional chronology according to the Corpus Christianorum 2, 1627 as well as Timothy D. BARNES, Tertullian: A Historical and Literary Study, Oxford, Clarendon Press, 1971, p. 55 dates it between 198 and 204.

57 Cf. William P. LESAINT, Tertullain, Treatises on Penance: On penitence and On purity, (Ancient Christian writers, 28), Westminster, Newman Press, 1959, p. 9-12; Charles MunIER, Introduction, in Charles MUNIER (ed.), Tertullien: La Pénitence, (Sources chrétiennes, 316), Paris, Éditions du Cerf, 1984, p. 7-10-51; GOLDHAHNMÜLLER, Grenze [see n. 12], p. 353f.

58 LESAINT, Treatises [see n. 56], p. 41. Already Jerome expressed some uneasiness in one of his letters. Epistulae 58, 10 (CSEL 54, 539,9f): “Tertullianus creber est in sententiis, sed difficilis in loquendo." Similarly, see Claudio MiCAELLI, Introduction, in Tertullien, La Pudicité, (Sources chrétiennes, 394), Paris, Éd. du Cerf, 1993 , p. 99.

59 Especially since the strong influence of the classical-educational rhetoric had been gradually recognised in the works of Tertullianus (cf. Robert Dick SIDER, Ancient Rhetoric and the Art of Tertullian, (Oxford theological monographs), London/New York, Oxford Univ. Press, 1971; Jean-Claude FREDOUILLE, Tertullien et la conversion de la culture antique, Paris, Études Augustiniennes, 1972, Geoffrey D. DunN, Introduction, in Tertullian, (The early church fathers), London, Routledge, 2004, p. 17-21) and in De pudicitia in particular (Micaelli (s. Anm. 66), 99-116).

60 De pudicitia 1,10 (CC.SL 2, 1282,41-45). 
Agrippinus is hardly resilient, or is, more accurately, arbitrary ${ }^{61}$ In the De pudicitia is Tertullianus, as a devoted follower of the North African section of the New Prophets, criticizes the policy and practice of his personal contrary pardoning (i.e. readmitting sinners into the community and to the communion) sexually related post-baptismal sins, i.e., adultery and fornication.

After a long introduction in correspondence with the conventions of judicial rhetoric, ${ }^{62}$ Tertullianus points out that the Scriptures, if correctly interpreted, clearly decline to pardon those Christians who have committed adultery. In order to establish a balance between the mercy of God and his justice, ${ }^{63}$ he introduces a distinction between sins that are to be forgiven on earth (peccata remissibilia) and those that are not to be forgiven (delicta inremissibilia), ${ }^{64}$ inter alia the "deadly sins" ${ }^{\circ 5}$ like idolatry, homicide, and adultery. ${ }^{66}$ While, according to Tertullianus, there is a broad consensus concerning the first two delicta, only adultery had recently become an issue. His position is unambiguous: on one hand, an adulterer is to be excluded not only from the community itself but also from the chance of being pardoned in general. ${ }^{67}$ On the other, the Carthaginian never denies the mercy of God. Pardon will be granted in heaven in both cases,${ }^{68}$ but he questions the authority of the church to perform it on earth. To support his views, he discusses, or rather reinterprets ${ }^{69}$ the parables of the "lost sheep", "lost drachma" and "prodigal son" from the Gospel of Luke. He even admits that at first glance they might support a lenient practice towards the adulteress. His thorough investigation reveals, however, that the parables do not refer to Christian sinners but to the gentiles. It is permitted to grant pardon for idolatry or adultery in the paenitentia prima (which is carried out before the baptism) for pagans, but definitely not in the paenitentia secunda for Christian sinners. ${ }^{70}$ Such a reading might appear as inconsistent compared to the Shepherd of Hermas, but is certainly not contrary to the teachings of the Gospels. ${ }^{71}$ In order to stress this argument, the Carthaginian

61 Cyprian mentions the name of Agrippinus several times (Epistulae 71, 4, 1; 73, 3, 1 [CC.SL 3C, 521,77; 532,49]) as "bonae memoriae uir" in the context of a synod "many years and long time ago". Epistulae 73, 3, 1 (CC.SL 3C, 532,48): “... anni sint iam multi et longa aetas...”. One knows, however, very little about this synod. Yvette DUVAL, Sur les conciles africains antérieurs à Cyprien, in Revue des Études Augustiniennes, 49 (2003), p. 239-243 argues, however, that the meagre evidence does not support an early dating in the times of Tertullianus.

62 See SIDER, Rhetoric [see n. 58], p. 24f; 35f; MICAELLI, Introduction [see n. 57], p. 99-116.

63 De pudicitia 2 (CC.SL 2, 1284,1-1286,3).

64 De pudicitia 2,12 (CC.SL 2, 1285,50-53).

65 "Delicta capitalia" in De pudicitia 9, 20; 21, 14 (CC.SL 2, 1299,89f; 1327,62f) or “delicta mortalia" in 3, 3; 19, 28; 21, 2 (CC.SL 2, 1286,13; 1323,125f; 1326,8) or "delictis maioribus" in 18,18 (CC.SL 2, 1319,82f) or "grauiora et exitiosa" in 19, 25 (CC.SL 2, 1323,112). See hereto also Reinhart STAATS, Hauptsünde, in Reallexikon für Antike und Christentum, 13 (1986), p. $751 \mathrm{f}$.

66 Cf. De pudicitia 5, 6-15; 12, 5 or, here, 19, 25, (CC.SL 2, 1288,23-1289,61; 1302,15-18; 1323,112-115):“Sunt autem et contraria istis, ut grauiora et exitiosa, quae ueniam non capiant, homicidium, idololatria, fraus, negatio, blasphemia, utique et moechia et fornicatio, et si qua alia uiolatio templi Dei."

67 De pudicitia 3-4 (CC.SL 2, 1286,1-1287,19).

68 De pudicitia 3, 3-6; 18, 18; 19, 6 (CC.SL 2, 1286,9-26; 1319,78-83; 1320,23-29).

69 While Tertullianus claims in De paenitentia 7-9 (CC.SL 1, 306,1-310,21) that the "lost parables" refer to Christians, he maintains in De pudicitia 7-10 (CC.SL 2, 1292,1-1301,67) the opinion that they concern (only) the gentiles.

70 De pudicitia 7-10 (CC.SL 2, 1292,1-1301,67).

71 De pudicitia 10, $12 \mathrm{ff}$ (CC.SL 2, 1301,45-67). To the conjectural method of Tertullianus see SIDER, Rhetoric [see n. 
offers an examination of the examples of Jesus as well as His actions:

Exinde quod ad euangelium pertinet, parabolarum quidem discussa iam quaestio est.Si uero et factis aliquid tale pro peccatoribus edidit dominus, ut cum peccatrici feminae etiam corporis sui contactum permittit lauanti lacrimis pedes eius et crinibus detergenti et unguento sepulturam ipsius inauguranti, ut cum samaritanae sexto iam matrimonio non moechae, sed prostitutae, etiam quod nemini facile, quis esset ostendit, nihil ex hoc aduersariis confertur, et si iam christianis ueniam delictorum praestitisset. Nunc enim dicimus, soli domino hoc licet, hodie potestas indulgentiae eius operetur. ${ }^{72}$

"As far as the Gospel is concerned, we have now thoroughly investigated the question of the parables. But if the Lord, by His actions also, favoured sinners in some similar way, as, for example, when He even permitted a sinful woman to touch His body, washing His feet with her tears and drying them with her hair and, with ointment, making preparation for His burial, and as when he showed the Samaritan woman (whose sixth marriage made her not so much an adulteress as a prostitute) who He was, something He did not readily do for anyone-this in no way favours our adversaries, even if He had granted pardon to those who were already Christians. For we say now: 'This is allowed to the Lord alone. May His power to pardon be at work in our own day!"'73

The North African refers here to two female figures from the Gospels. The first one is a "woman, a sinner" who touches Jesus and washes his feet according to Lk. 7,37f. Although the Gospel does not specify her sin—she is simply described as a "sinner" ( $\dot{\alpha} \mu \alpha \rho \tau \omega \lambda$ ó $\varsigma)$ - he classifies it selfevidently as adultery. ${ }^{74}$ The other woman is from Samaria, who had, according to Jn. 4,17f, six husbands. Tertullianus, seeing himself as a champion for monogamy in the strictest ${ }^{75}$ sense, comments on it sarcastically: she is not an adulteress but in fact a prostitute. ${ }^{76}$ For him, both references are in their main aspects comparable: they are both women, both committed (whether assumed or due to successive polygamy) adultery, and-most substantially for the case-Christ personally pardoned or respectively revealed himself to them. Despite these instances of Christ "favouring sinners", Tertullianus denies the possibility of pardoning: even if the Saviour would pardon grave sins of Christians in person, the scope of his actions and their legitimacy would be

58], p. 41-73; 91.

72 De pudicitia 11, 1f (CC.SL 2, 1301,1-1302,10).

73 Translation by LESAINT, Treatises [see n. 56], p. 83, with some modification.

74 The four Gospels present three different accounts, in detail, of the story of anointing in Bethany. Mt. 26,6f in accordance with Mark 14,3f refers to a woman without any further specifications. There is no mentioning of any kind of $\sin (s)$ or repentance, rather a radical critique of the woman by the disciples. Jn. 12, $3 f$ extends this account with an identification of the woman with Mary, the sister of Martha and Lazarus. It is remarkable that while contemporaries of Tertullianus restrain themselves to specify the sin of the woman, the Carthaginian stigmatises her also in one of his other works - the only other reference of this passage in his corpus-as an adulterer. Cf. Adversus Marcionem 4, 18, 9 (CC.SL 1, 591,13-21); Ps. Cyprianus, Ad Nouatianum 11, 1 (CC.SL 4, 145,6f); Clemens Alexandrinus, Paedagogus 2, 61 (GCS Clemens 1, 194,1); Origenes, Commentarii in Matthaeum I, 12, 4 (GCS Origenes 10, 75,12); Commentarii in Matthaeum 2, 77 (GCS Origenes 11, 178,30; 180,9; 181,2; 183,10); Commentarii in Iohannem 1, 67 (GCS Origenes 4, 16,23).

75 As a follower of the New Prophecy, Tertullianus defends the strict uniqueness of marriage and decline a remarriage of no matter of what reason in the tract De monogamia.

76 One can observe here increasing radicalism: in contrast to De pudicitia, he declared the Samaritan women in De monogamia "just" as an adulteress, which corresponds to the text of the Gospel. De monogamia 8,7 (CC.SL 2, 1240,40-58). 
limited exclusively to him. ${ }^{77}$ In other words, Christ has the God-given authority to pardon those sins, but this authority is not inherited in the "church as a number of bishops" "78. The motto here is: "Quod licet Iovi, non licet bovi." ${ }^{, 79}$ It is notable that although Tertullianus explicitly refers to two "adulterous" women who were engaged in a social interaction with Jesus, he does not mention the narrative of the adulteresses at all. This is particularly peculiar since the PA would have been an exceptionally pertinent example of the mercy of Jesus and that of his favour towards sinners. And yet, all there is, is silence. ${ }^{80}$

In a later passage, Tertullianus attacks his personal adversary and disqualifies him from pardoning adultery by introducing a distinction between the discipline (disciplina) of the apostles and their spiritual power (potestas). He claims that potestas is awarded directly by God exclusively to his chosen ones such as the apostles, prophets, true martyrs, and, naturally, to the followers of the New Prophecy. ${ }^{81}$ These are qualified by their potestas to pardon even capitals sins. ${ }^{82}$ On the contrary, his adversary has only been entrusted with the authority to govern disciplina. He is of course most welcome to prove his pneumatic gift by exhibiting his prophetic charisma. ${ }^{83} \mathrm{With}$ this distinction, the North African is doing nothing less than degrading his episcopal rival to, if anything, a second class bishop of a second class church.

In accordance with the recommendation of the ancient rhetorician Quintilianus ${ }^{84}$, Tertullianus, "permits" his opponent to present his arguments in order to defend his position. The quoted counterargument that "the Church [...] has the power to pardon sins" 85 , is not particularly sophisticated. However, on one hand, the Carthaginian shows himself in agreement with the counterargument. On the other, he limits its scope by referring to one of the oracles of the Paraclete, i.e. to a piece of oral tradition: "The Church can pardon sin; but I will not do it, lest they also commit other sins." 86 The anonymous bishop tryes to exclude this "spiritual" objection by questioning the authority of the oracle: "Quid, si pseudopropheticus spiritus pronuntiauit?"87 Thereupon, he claims—by running out of arguments, or equally probable, Tertullianus lets him run

77 De pudicitia 11, 2 (CC.SL 2, 1302,9f): “..., soli Domino hoc licet, ...”.

78 De pudicitia 21, 17 (CC.SL 2, 1328, 76ff): "Et ideo ecclesia quidem delicta donabit, sed ecclesia spiritus per spiritalem hominem, non ecclesia numerus episcoporum."

79 Terentius, Eauton Timorumenos 797.

80 To De pudicitia 11, 1 (CC.SL 2, 1301,1-1302,9). On this LESAINT, Treatises [see n. 56], p. 235, n. 294 noted perceptively: "the omission furnishes a rather good argument from the silence that the passage was not found in the Gospel texts with which he and his adversaries were familiar." This important observation received only marginal attention in the scientific discourse.

81 De pudicitia 21, 1-4 (CC.SL 2, 1326,1-19).

82 De pudicitia 21, 4 (CC.SL 2, 1326,14-19).

83 De pudicitia 21, 5 (CC.SL 2, 1326,20-24).

84 Quintilianus suggested citing the arguments of one's adversaries, when they are stressing their own weaknesses. Institutio oratoria, 5, 13, 12.25ff.

85 De pudicitia 21, 7 (CC.SL 2, 1326,27-31).

86 De pudicitia 21, 7 (CC.SL 2, 1326,29f): "Potest ecclesia donare delictum, sed non faciam, ne et alia delinquant".

87 De pudicitia 21, 8 (CC.SL 2, 1326,31f). 
out of arguments-, that Peter has been given the keys of pardoning according to the Gospel. ${ }^{88}$ Finally, his struggle (or, possibly, the struggle Tertullianus "causes" for him) reaches so far that he is forced to refer to the Shepherd of Hermas to defend his penitential practice. ${ }^{89}$

The reproduced reasoning of the bishop appears here as a quite crude attempt to gain ground, especially in comparison to Tertullianus' carefully polished train of thought. But there is more to come. It is conspicuous that the vast majority of the counterarguments presented by his opponents are neither legitimated by the Scriptures, nor by the traditio of the (true) church, nor by the rule of faith, nor directly inspired by the Paraclete. Consequently, they are lacking authority. In the face of a shortage of arguments and the absence of legitimacy, it is fairly surprising that the bishop refrains from invoking the PA as "bullet-proof" evidence. At least according to the De pudicitia, the bishop makes no attempt of that sort. In any case, the Shepard does not cause Tertullianus a serious headache: in no time he disqualifies it as an apocryphon, ${ }^{90}$ and therefore as a meaningless piece of literature.

The question of to what extent Tertullianus could have modified or withheld the arguments of his adversaries when he compiled De pudicitia is an unsolved issue: on one hand, his education in rhetoric as well as his "emotional" approach suggest that he is not necessarily the master of what one would nowadays consider a correct citation. Rather, he sacrifices an accurate quotation or a line of reasoning with ease on the altar of a good argument. On the other hand, he obviously endeavours to present, discuss and disprove a wide range of different arguments maintained by his rival. ${ }^{91}$ It would also be a considerable possibility that he deliberately omitted uncomfortable elements, such as the PA, from the reasoning of his opponents. Even though the story has the potential to be highly persuasive against his own position (provided that it is considered to be an authoritative text as part of the Scriptures commonly used in Carthage), it is nevertheless unlikely that it fell victim to the ignorance of Tertullianus because of ideological or theological aversions. In case he knew the PA, it would - from his perspective- hardly have been a crucial, not to mention a discussion-ending, argument. The methodology he developed and applied to the other "adulteresses" would have also disqualified this narrative with ease. All he needed to do was to add the adulterous woman of the

88 Mt. 16,18; De pudicitia 21, 9 (CC.SL 2, 1327,37-43).

89 The Shepherd of Hermas was widely read in early Christianity and obviously had a great impact also in Carthage. Tertullianus maintains, however, a quite ambivalent relationship to it. In one of his earliest extant works, $D e$ paenitentia, he frequently makes use of it and adopts its views on the paenitentia secunda, but relinquishes an explicit reference to his source. His esteem of Hermas drops gradually with his growing sympathies towards the New Prophecy movement. In De oratione 16, 1-4 (CC.SL 1, 265,14-266,10), written between 198 and 204, he mocks Christians in Carthage who utilise one particular part of the Shepherd as a model for church discipline. In De pudicitia he has no more flattering words to say; he disqualifies it rather as an apocryphal work of little value which is only well-disposed towards adulterers. Cf. n. .

90 De pudicitia 10, 12 (CC.SL 2, 1301,45ff): "Sed cederem tibi, si scriptura 'pastoris', quae sola moechos amat, diuino instrumento meruisset incidi, si non ab omni concilio ecclesiarum, etiam uestrarum, inter apocrypha et falsa iudicaretur...", See also, similarly: De pudicitia 20, 2 (CC.SL 2, 1324,7-11).

91 Some arbitrary examples should illustrate his efforts: De pudicitia 5, 15- 6, 1; 7, 8f; 10, 9-12; 15,8 ect. (CC.SL 2, 1289,56-6; 1292,31-1293,38; 1301,35-53, 1311,29-34). 
PA into the "hall of fame" and call into attention that she was neither a Christian. A serious threat to his argumentation, which might have forced him to ignore the story, must look different. The challenge is even smaller if he had learnt the story from the counterargument of his adversaries, or, respectively, if he had known it from the oral tradition. In both cases, he could have-and certainly as a good orator he would-apply a recommendation of Quintilinaus ${ }^{92}$ : to declare it a forgery, a non-authoritative piece of tradition in contrast to the "true" regula fidei, or, alternatively, to brand it as an apocryphon (or as an apocryphal addition), as he did previously with the Shepherd of Hermas. ${ }^{93}$ But there is even more to gain for the rhetorician: such a clumsy attempt can easily be used to demonstrate once again the ridiculously weak arguments of the "Catholics" far beyond the regula fidei, or in fact of any kind of authority. Consequently, when the PA is only circulated as non-scriptural tradition and particularly when his opponents try to exploit it, it is rather likely that Tertullianus would have referred to it, and instantly disqualify it, rather than ignoring or even disguising it because of ideological or theological reasons.

\section{The manuscript tradition}

Whether Tertullianus employs Greek texts in his writings by translating them or is able to use an already existing Latin translation is the subject of a long and quite controversial discussion. ${ }^{94}$ Despite the painstaking endeavours of several experts, convergent conclusions have not (yet) been reached..$^{95}$ In the light of his quotation technique it is not surprising: quotations of the Scriptures are rarely presented in the same form twice. Furthermore, they are often so divergent from each other as well as from the extant Old Latin and Greek texts that it seems to be impossible to connect them unambiguously to the "African" versions, to other text-types of the Vetus Latina, or to the Greek versions.

92 Institutio oratoria $5,5,1$.

93 De pudicitia 10, 12 (CC.SL 2, 1301,45-53).

94 To the status questionis see Philip BURTON, The Latin Version of the New Testament, in Bart D. EHRMAN, Michael W. Holmes (ed.), The Text of the New Testament in Contemporary Research: Essays on the Status Quaestionis, (New testament tools, studies and documents, 42), Leiden/Boston, Brill, ${ }^{2} 2013$, p. 177ff.

95 The question, whether Tertullianus employed in his writings an already existing Latin translation or he translated the passages' ad hoc from Greek, is difficult to decide. When he uses the same passage in different works, they appear in many cases more or less, but are divergent from each other. Furthermore, it seems that he quoted frequently from memory; sometimes also the accuracy of the citations has shortcomings. See G. J. D. AALDERS, Tertullian's Quotations from St Luke, in Mnemosyne, 5 (1937), p. 279-282. Nonetheless, it is certain that he had access to Latin translation(s) of the Scriptures. In De Monogamia 11, 11 (CC.SL 2, 1246,81), he contrasts the Latin reading of 1Cor 7,39 with the "Graeco authentico". A closer determination is, however, problematic: his quotations regularly do not overlap with the majority of the extant Vetus Latina variants. Cf. Thomas P. O’MALLEY, Tertullian and the Bible: Language-Imagery-Exegesis, (Latinitas christianorum primaeva, 21), Nijmegen, Dekker \& van de Vegt, 1967; Geoffrey D. DunN, Tertullian, (The early church fathers), London, Routledge, 2004, p. 14f; Hugh A. G. Houghton, The Latin New Testament: A Guide to its Early History, Texts, and Manuscripts, Oxford/New York, Oxford Univ. Press, 2016, p. 5f. To the citation techniques and conventions in the early patristic period as well as to their problems see Charles E. HILL, 'In These Very Words': Methods and Standards of Literary Borrowing in the Second Century, in Charles E. Hill (ed.), The Early Text of the New Testament, Oxford, Oxford Univ. Press, 2012 with further literature. 
The Old Latin manuscript tradition is hardly illuminative for the case of Tertullianus. The vast majority of manuscripts that are not lacunate, incorporate it at the currently known position and are of later date. ${ }^{96}$ The main representative of the "African" text-type, the Codex Palatinus $(e, 02)$, represents likewise a post-Cyprianus development ${ }^{97}$. The oldest exemplar of this text-type, the Codex Bobiensis $(k, 01)$, is strongly fragmented, inter alia the Gospel of John is missing. The codices that omit it belong either to the group of the "European" tradition or to the "mixed texts". 98 On the contrary, the Greek manuscript tradition is rather instructive. It is well documented that the $2^{\text {nd }}$ and $3^{\text {rd }}$ century Greek manuscripts' copies of John omit the PA in unison. ${ }^{99}$ Since it is likely that Tertullianus used Greek texts in his work directly as well, it is also likely that the copy (or copies) he has been relied on, did not include the passage either. In other words, in the light of the extant Greek manuscripts it is far more probable that he had not learnt the story from the Greek manuscripts rather than that he had read, but consistently ignored, it. This evidence can be used also in the opposite direction: since it is likely that Tertullianus did not know the PA, it is also likely that his copy of the Greek text omitted the passage. The earliest extant Greek account of the story supports such a theory. It appears first rather late, around 400, in the Greek-Latin diglot Codex Bezae ( $d$, for the Greek text $D, 05) .{ }^{100}$ The quality of the Greek text is poor, it is corrupted by back-translations and additions delivered from the Latin. ${ }^{101}$

Important additional evidence for the early presence of the PA in the Western scriptural tradition is presented by T. Wasserman in an analysis. ${ }^{102}$ The vast majority of the chapter division systems in the Vetus Latina and their titles (capitula) list PA in the today known position (fourteen out of fifteen different types for the Gospel of John), one omits it. ${ }^{103}$ The "Type Cy"104 represents the most significant variation for the origins of PA. According to Hugh A. G. Houghton it is "earlier than that of any surviving Old Latin manuscript of John", because it is "accompanying a revision of the African text of the Gospels represented by Codex Bobiensis (VL 1) prior to Cyprian's quotations

96 Cf. O’Loughlin, Plight [see n. 3], p. 86. Cf. Adolf Jülicher (ed.), Itala, Berlin/New York, de Gruyter, 1963, p. 83-87; FISCHER, Varianten [see n. 3], p. 242-278; WASSERMAN, Missing [see n. 10] and compare to the results of the online tool at http://iohannes.org/vetuslatina/edition/index.html.

97 Cf. Philip Burton, The Old Latin Gospels: A Study of their Texts and Language, (Oxford early Christian studies), Oxford/New York, Oxford University Press, 2000, p. 19; similar in BURTON, Latin Version [see n. 93], p. 177ff.

98 Codex Vercellensis $(a, 02)$; Codex Corbeiensis $\left(f f^{2}, 08\right)$; Codex Brixianus $(f, 10)$, Codex Rehdigeranus $(l, 11)$; Codex Monacensis, $(q, 13)$ and Codex Interlinearis Sangallensis $(\delta, 27)$. For a short characterisation and further references see BURTON, Gospels [see n. 96], p. 20-29.

99 Cf. Wasserman, Missing [see n. 10], p. 37-47.

100 See hereto David C. PARKER, Codex Bezae: An Early Christian Manuscript and its Text, Cambridge/New York, Cambridge Univ. Pr., 1992, p. 261-286.

101 Cf. ibidem, p. 250-258.

102 See WASSERMAN, Missing [see n. 10], p. 60-62.

103 The PA is omitted only in "Type Ifor", based exclusively on the text of Codex Foroiuliensis. For the complete catalogue see ibidem, p. 60, n. 105.

104 This type of capitula is preserved in two manuscripts, from the final third of the ninth-century Vatican, Barberini Lat. $637(\mathrm{Vb})$ and from the first third of the ninth-century Munich, BSB Clm. $6212(\mathrm{Yb})$. See also Donatien de BRUYNE, Quelques documents nouveaux pour l'histoire du texte africain des Evangiles, in Revue bénédictine, 27 (1910), p. 316-324; 442. 
and Codex Palatinus" and display "affinities to the citations of both Cyprian and Tertullian"105. Despite of the overall importance of "Type Cy", it had no impact on Tertullianus and on his knowledge of the PA, in general, because "affinities" to patristic citations cannot indicate dependency, ${ }^{106}$ and in particular, because apparently no affirmative link exists between "Type Cy" and the work of Tertullianus. ${ }^{107}$

A further capitulum, "Type I", the most common and widespread in the Vetus Latina tradition, reflects "a very ancient Old Latin text [because it is using] the rare Greek loanword moechatio", "which was later replaced with the noun adulterium"108. It seems, however, that the literal engagement of these two words is more complicated than what one would expect. First of all, the word-form moechatio is indeed an almost unique expression. ${ }^{109}$ Moechia is transliterated from $\mu o \imath \chi \varepsilon i ́ \alpha$ and shares the same root and meaning with moechatio, appearing first in the works of Tertullianus in Christian ${ }^{110}$ literature. It is frequently attested in De pudicitia ${ }^{111}$ and occurs in the following period predominantly, but not exclusively, in writings of North African Christian authors. ${ }^{112}$ Tertullianus uses moechia because it is, according to him, a commonly accepted terminus technicus for adultery in the local Christian communities around $220 .{ }^{113}$ Such a claim

105 Hugh A. G. Houghton, Chapter Divisions, Capitula Lists, and the Old Latin Versions of John, in Revue Bénédictine, 121 (2011), p. 337f.

106 In this context, I would like to express my gratitude to Hugh A. G. Houghton for his valuable insights on the Old Latin tradition and the capitula.

107 While Donatien De Bruyne provides a nearly endless list of the "affinities" between the biblical text extant in "Type Cy" and Cyprianus, he indicates only three "affinities" within the oeuvre of Tertullianus. The first one concerns the capitulum LXIII in Lk. 10,1: “Ubi elegit et alios LXXta et misit euso dicens...". BRUYNE, Documents [see n. 103], p. 258; 311. Tertullianus quotes the same passage in Adversus Marcionem 4, 24, 1 (CC.SL 1, 607,23f): "Adlegit et alios septuaginta apostolos super duodecim.". Apart from the fact that both take note of the Septuaginta, there is little similarity between the two quotations. The capitulum LXXXVIII of the same Gospel is irrelevant: the reading of the chapter division is not supported by Tertullianus, but the reading of the " $e$ "' is. Cf. ibidem, p. 287; 314. Finally, capitulum XXVI, which refers to Jn. 7,28, reads as follows: "Ubi medio die festo ascendit in templo, et ammirantibus iudaeis quod litteras non didicerit multa ibi locutus est de doctrina quae a patre est, de voluntate patris, de circumeisione in sabbato, et quia non illum nouerant nec unde esset nec a quo missus esset." Tertullianus quotes the same passage in Adversus Praxean 22, 1 (CC.SL 2, 1189,2-6): "Aeque ambigentibus inter se ne ipse esset christus, utique non pater sed filius: me que scitis, inquit, unde sim; et non ueni a me ipso, sed est uerus qui me misit, quem uos non nostis; ego noui illum, quia apud illum sum." According to De Bruyne, the "affinity" is represented by the fact that, apart from " $r$ ", only Tertullianus negates the first two instances. ibidem, p. $291 ; 318$.

108 WASSERMAN, Missing [see n. 10], p. 61.

109 Ps-Cyprianus, De singularitate clericorum 28 (CSEL 3/3, 204,25) by quoting 2Pet. 2,14; in the versio vulgata of Hermas, Mandata 4, 1, 9 (TU 173, 60,16); Doctrina apostolorum 5, 1 (SC 248, 209,66); De adulterinis coniugiis 1, 9, 9 (CSEL 41, 356,13) in an allusion to Mt. 19,9.

110 For the usage in the non-Christian Latin literature, see Innocenzo MAZZINI, Due esempi di traduzione biblia pregeronimiana: moechatio ed hauritorium, in Vetera Christianorum, 10 (1973).

111 Tertullianus uses this word not less than 40 times in the mentioned work. E.g., De pudicitia 1, 6; 1, 15; 1, 19f; 2, $16 ; 4,1 ; 4,4 ; 5,1$ etc. (CC.SL 2, 1282, 28; 1283,67; 1283,80-91; 1286,67; 1286,3f; 1287,14f; 1287,1).

112 See, e.g., Clemens (Romanus), Epistula ad Corinthios secundum translationem latinam, 30, 1 (FlorPatr 44, 35,16); Ps-Cyprianus, De aleatoribus 5 (CSEL 3/3, 97,4); Commodianus, Instructionum, 1,11 (CC.SL 128, 9,2); Augustinus, Sermones 8, 12 (CC.SL 41, 89,263); Hilarius Pictauiensis, Tractatus super psalmos In psalmum 118, Samech 6 (CC.SL 61A, 144,17) in a quotation from Mt. 15, 19f. Furthermore, the Codex Palatinus attests the word at Jn. 8,4: "... haec mulier depraehensa est sponte moecata".

113 In the fourth chapter of De pudicitia, Tertullianus specifies and justifies his terminological decisions. First, he equates fornicatio with moechia according to the usus, i.e., "common usage": "Inprimis quod moechiam et fornicationem nominamus, usus expostulat." Afterwards, he claims to follow the "accepted usage" of "certain 
confirms his quote of the sixth commandment. He is rendering it with "non moechaberis" "114, delivered from $\mu$ oเ $\chi \tilde{\alpha} \sigma \vartheta \alpha$, likewise related to moechatio. This particular reading, his claim , and the constant form implies that the phrase was indeed commonly spread in Carthage at his time. That Jerome prioritises this form rather than using the Latin equivalent adultero when he compiles the Decalogue for the Vulgate points in the same direction. Therefore, it is particularly surprising that the capitulum XXX in "Type Cy", a witness for the presence of the PA in the Old Latin tradition of which it is certain that it is as early as it is African, uses adultera to name the adulteress. ${ }^{115}$ Tertullianus as a slightly earlier witness knows and uses the word moecha instead to describe the Samaritan woman. ${ }^{116}$ In addition, it is remarkable that various forms of the root moech-are overwhelmingly used by authors of North African provenance. ${ }^{117}$ Consequently, the rendering of the early biblical text preserved in the "Type Cy" implies that the Latin word adultera and the Greek loanword moecha coexisted ${ }^{118}$ rather than that one had been replaced by the other. Such a tendency is likewise observed in other Old Latin witnesses as well as North African Christian authors. ${ }^{119}$ In terms of dating, the widespread references from the Latin translation of Clemens Romanus ( $2^{\text {nd }}$ or $3^{\text {rd }}$ century) until Commodianus ${ }^{120}$ provide even in the best possible scenario nothing more than a terminus post quem for its usage. The frequent but not exclusive attendance of the different word forms among the Christian authors of North African provenance suggests, however, that it can provide a geographical classification rather than a chronological one. Because the origins of the word cannot be reconstructed before the age of Tertullianus, ${ }^{121}$ and the adoption of a particular expression into the common language can happen very quickly, this evidence is hardly reliable for a dating of the presence of the PA in the Vetus Latina tradition far before 200. Because of the same reason, it is not less problematic to use the "loanword phenomenon" to confirm the originally Greek language of the initial text. ${ }^{122}$

familiar terminology" that is employed by"faith": "Habet et fides quorundam nominum familiaritatem. Ita in omni opusculo usum custodimus." In other words, Tertullianus alleges to maintain in the Christian communities commonly known and used terminology concerning adultery. It remains, however, uncertain whether it corresponds to the custom of the New Prophets, to the "Catholics", or to both of them. Finally, he emphasises that these terms are in their meaning entirely indifferent to the terminus technici employed in jurisprudence, adulterium and stuprum: "Ceterum et si adulterium et si stuprum dixero, unum erit contaminatae carnis elogium." De pudicitia 4, 1f (CC.SL 2, 1287,1-6).

114 De pudicitia 5, 1; 5, 5; 6, 5.6 (CC.SL 2, 1287,8; 1288,18; 1290,21; 1290,24) or Adversus Judaeos 2, 3 (CC.SL 2, 1341,19).

115 BRUYNE, Documents [see n. 103], p. 291: “Ubi adulteram dimisit et se dixit lumen saeculi...”.

116 De pudicitia 11, 1 (CC.SL 2, 1301,2): "Ut cum samaritanae sexto iam matrimonio non moechae, sed prostitutae".

117 Apart from the references mentioned above, moechatio is attested in the Codex Corbeiensis $\left(f f^{2}\right)$ in Jn. 8,3 and 8,4. The form moechor appears in Jn. 8,4 in the Codex Palatinus (e).

118 Another explanation of the phenomenon would be that one terminus or the other was used only in a geographically restricted area of North Africa.

119 Cf. n. for the Old Latin witnesses and n. especially the oeuvre of Augustinus.

120 Very little is known about the life of Commodianus. Even the century he is supposed to have lived in is a subject of controversial discussions. Most common are positions suggesting the $3^{\text {rd }}$ or the $5^{\text {th }}$ century.

121 See WASSERMAN, Missing [see n. 10], p. 62f.

122 Cf. ibidem, p. 61. 
In final consequence, the insights of the manuscript tradition are barely illuminative for the silence of Tertullianus. The most important result is that they are not interfering with the hypothesis. A dating based on the capitula, if at all, does not reach considerably beyond the dating established on the basis of the Old Latin manuscript tradition. Various terms based on the root moech- in some Vetus Latina manuscripts and in a handful of chapter divisions suggest instead a North African "touch" on the formation of the passage.

\section{Conclusion}

By nature, it is more difficult to explain the absence of a certain thought or motif in a text than to give a (plausible) reason for its presence. While the textual, historical, and other contexts help to reduce the available options for a determination of the inclusion, the reasons for the absence can be manifold. A closer investigation of a missing element is therefore rather complicated; absent evidence reasoning is methodically questionable. ${ }^{123}$ Although "the argument from silence cannot be logically conclusive" it can be rationally "conclusive [...] under a very stringent set of conditions"124. Based on the considerations of Charles-Victor Langois (1863-1929) and Charles Seignobos (1854-1942), John Lange presents such a set of conditions regarding (historical) events. ${ }^{125}$ With only a few modifications - the case of Tertullianus focuseson a missing literary reference and not on a certain historical event-the preset conditions can be applied here as well. First, it has to be expected that the author has access to all the necessary documents in order to learn about the subject that is not mentioned. Second, the author has to have the intention to present an elaborated and comprehensive account on the topic that is relevant for the unmentioned subject. And finally, the subject is important enough for the author to mention it.

The third condition, the urgency for Tertullianus to deal with the PA, arises directly from the conflict the North African is deeply involved in: the pardoning of adultery. The Sitz im Leben as well as the genre of the main witness to the controversy, the De pudicitia, leaves him little choice:

123 An argumentum ex silentio is usually considered as unreliable with a strong tendency to fallacy. For instance Zane Clark HodgeS, The Woman Taken in Adultery (John 7:53-8:11): Text, in Bibliotheca sacra, 136 (1979), p. 330 claims in the context of the PA that "the argumentum ex silentio notoriously tenuous and inconclusive" and therefore the "value of the Fathers who say nothing is accordingly minimal", a verdict that is shared by PUNCH, The Pericope Adulterae [see n. 7], p. 333. One of the handful of essays, however, which are undertakes the burden of engaging with the argument from silence as part of the historic analysis, concludes that the "interpretation of the strength or weakness of an AFS [argument from the silence] should proceed case-by- case" (Mike DuNCAN, The Curious Silence of the Dog and Paul of Tarsus: Revisiting The Argument from Silence, in Informal Logic, 32 (2012), p. 96) because "there are no good general dialectical rules to follow" (ibidem, p. 85). Furthermore, "persuasiveness often depends on a subtle assessment of factors, primarily relating to the likelihood of documentation being available in a given type of case". John LANGE, The Argument from Silence, in History and Theory, 5 (1966), p. 301.

124 LANGE, Argument [see n. 122], p. 301 and 290.

125 "(1) There is a document, D, extant, in which the event, E, is not mentioned. (2) It was the intention of the author of $\mathrm{D}$ to enumerate exhaustively all members of the class of events of which $\mathrm{E}$ is supposed to be a member. (3) The author of D was acquainted with all members of the class in question. (4) E must be such that, if it had occurred, the author of D could not have overlooked it." ibidem, p. 290. 
the story could have a good use for his purpose, because it is an illuminative example of "favouring sinners" by Jesus. It would have fitted seamlessly into his argumentation, and the same reasoning could easily "disarm" it that which he had invented by dealing with the other "adulterous" women. Even if Tertullianus-due to an unknown ideological or theological reason-intended to misappropriate the PA, his opponents would have referred to it: Jesus not only reveals himself as the Saviour but pardons expressis verbis an adulteress. A better and even more authoritative counterargument can hardly be found. The Carthaginian cannot ignore such an incisive and persuasive argument, especially not in a work composed by following the conventions of a defence speech before a court (genus iudiciale). His main aim is to convince the judge, which is in this case the reader, that he is right and the "sensualists" are wrong. A concealment would be more than disastrous, particularly when the audience would have known the story of the adulteresses. Tertullianus would endanger his entire argumentation if he appeared imprudent before his target group. Consequently, the story would not only have been important to Tertullianus to engage with, but most likely also indispensable.

Whether his account is comprehensive or not is difficult to decide at a general level. Such a decision has to be made instead on a case by case basis. On one hand, he never wrote a commentary on the Scriptures and he can hardly be described as a systematic theologian, particularly not in his polemic writings. On the other hand, his oeuvre displays a broad and continuous interest in matters of martial togetherness and in the limits of pardoning. De pudicitia, for instance, is dedicated exclusively to the very same topic as the Leitmotiv of the PA. Nonetheless, the work and its argumentation is highly tendentious. At the same time, Tertullianus presents and discuss his own views as well as those of his opponent. His efforts to support his position with authorities-predominantly the Scriptures, but also the non-written tradition or even examples from the pagan environment ${ }^{126}$ - are as omnipresent as they are impressive. More specifically, in De pudicitia Tertullianus discusses cases when Jesus was favouring female sinners. Apart from the story of the woman caught in adultery, he mentions all the other relevant and available Gospel narratives on the topic. In this aspect, his account could definitely be considered as complete, would he allude to the PA.

Finally, to the first condition: if the story had already been an integral part of the fourfold Gospels in North Africa at the time of Tertullianus, he would have known it. In case the PA circulated as extra-scriptural, a determination is rather difficult. Because of the fact that both, Tertullianus and his "sensualist" opponents use non-scriptural but authoritative traditions to support their arguments, the possibility of a reference appears rather likely. What is more, his adversaries must have had an enormous interest to refer to the PA, particularly in the light of their struggles to 
legitimate their "lenient" position.

All things considered, one can draw a conclusive conclusion from the available evidence within the corpus of Tertullianus, because all three conditions can be approved. Consequently, it is rather likely that the Scriptures used by Tertullianus, by the "Catholics" in Carthage, and by his supposed readers did not include the story. Similarly, the PA is likely not part of the non-scriptural tradition either, at least not as an authoritative narrative worth mentioning. The chances that the story was known at the beginning of the $3^{\text {rd }}$ century in Carthage (and possibly in the western part of the North African provinces, dominated by Carthage at this time), are very small. 